\title{
Gambaran Kepatuhan Diet Pada Pasien Diabetes Mellitus Di RSUD dr. M. Yunus Bengkulu Tahun 2018
}

\author{
Feni Eka Dianty, Yusran Hasymi, Dea Ade Merisca \\ Program Studi DIII Keperawatan Fakultas Matematika dan Ilmu Pengetahuan Alam \\ Universitas Bengkulu \\ Email : fenieka1973@gmail.com
}

\begin{abstract}
ABSTRAK
Diabetes mellitus adalah salah satu penyakit dengan prevalensi yang terus meningkat. Hasil pengumpulan data diabetes mellitus di RSUD Dr. M. Yunus Bengkulu selalu mengalami peningkatan di setiap tahunnya, yaitu tahun 2015 terdapat 355 orang, tahun 2016 terdapat 359 dan tahun 2017 terdapat 369 orang. Terdapat lima pilar dalam penatalaksanaan diabetes mellitus, yaitu diet, latihan, pemantauan, terapi dan pendidikan. Kepatuhan diet penting untuk menjaga kontrol kadar gula dalam darah. Penelitian ini bertujuan untuk mengetahui gambaran kepatuhan diet pada pasien diabetes mellitus di ruang poliklinik RSUD Dr. M. Yunus Bengkulu. Desain penelitian menggunakan studi kasus dengan responden 13 orang pasien diabetes mellitus yang rawat jalan di poliklinik RSUD Dr. M. Yunus Bengkulu. Hasil penelitian menunjukkan pasien yang mempunyai tingkat kepatuhan diet patuh terhadap terapi diet sebanyak 11 orang $(85 \%)$.
\end{abstract}

Kata kunci : Diabetes mellitus, kepatuhan diet.

\section{Overview Of Diet Compliance In Diabetes Mellitus Patients In RSUD Dr. M. Yunus Bengkulu In 2018}

\begin{abstract}
Diabetes mellitus is a disease with increasing prevalence. Diabetes mellitus data collection results at RSUD Dr. M. Yunus Bengkulu always experiences an increase every year, namely in 2015 there were 355 people, in 2016 there were 359 and in 2017 there were 369 people. There are five pillars in the management of diabetes mellitus, namely diet, exercise, monitoring, therapy and education. Dietary compliance is important to maintain control of blood sugar levels. This study aims to determine the description of diet adherence in patients with diabetes mellitus in the polyclinic of RSUD Dr. M. Yunus Bengkulu. The study design used a case study with 13 respondents of outpatient diabetes mellitus patients at the Polyclinic of
\end{abstract}


RSUD Dr. M. Yunus Bengkulu. The results showed that 11 patients (85\%) adhered to diet adherence to diet therapy.

Keywords: Diabetes mellitus, diet compliance

\section{PENDAHULUAN}

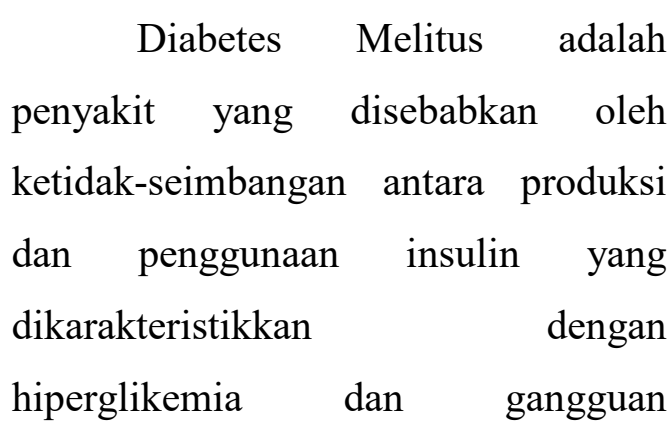

metabolisme karbohidrat, protein dan lemak. Diabetes melitus telah menjadi epidemis di Amerika Serikat dengan 21 juta orang (7\% dari populasi) mengidap penyakit ini. Kira-kira 15 juta orang terdiagnosis dengan Diabetes Melitus. Sekitar 6 juta diestimasikan menderita penyakit ini namun belum terdiagnosis. Sebagai salah satu permasalahan kesehatan yang cukup serius, diabetes melitus merupakan penyebab ke enam kematian yang terjadi di Amerika Serikat ( Black, 2009).

Diabetes Melitus (DM) adalah salah satu jenis penyakit degenerative yang mengalami peningkatan setiap tahun di negara-negara seluruh dunia. Menurut International of Diabetic Federation (IDF, 2015) tingkat prevalensi global penderita DM pada tahun 2014 sebesar $8,3 \%$ dari keseluruhan penduduk di dunia dan mengalami peningkatan pada tahun 2014 menjadi 387 juta kasus. Di Amerika, 24 juta orang atau 8\% dari total populasi mengalami DM dan DM menempati urutan ke 6 penyebab kematian di Amerika. Terdapat 57 juta orang mengalami pre-diabet atau mengalami peningkatan kadar gula darah yang lebih dari normal namun belum cukup bisa dikatakan diabetes mellitus. WHO membuat perkiraan bahwa pada tahun 2025 jumlah penderita diabetes meningkat menjadi 300 juta orang. Diabetes yang tidak terkontrol akan menyebabkan terjadinya beberapa komplikasi seperti penyakit jantung, hypertensi, retinopati, gangren diabetic yang berakhir pada amputasi, dan 
penurunan quality of life (American Association of Preferred Organization, 2010).

\section{Di Indonesia penyandang} diabetes diperkirakan sebesar 10 juta dan menempati urutan ke tujuh tertinggi di dunia. Prevalensi diabetes di Indonesia cenderung meningkat, yaitu dari 5,7\% tahun 2007, menjadi $6,9 \%$ tahun 2013. Indonesia merupakan negara yang berada di urutan ke-4 dengan prevalensi diabetes tertinggi di dunia setelah India, China, dan Amerika Serikat (Riskesdas, 2013).

Berdasarkan data Dinkes Provinsi Bengkulu pada tahun 2016 jumlah penderita Diabetes Melitus di provinsi Bengkulu mencapai 4.568 kasus (Dinkes Provinsi Bengkulu, 2016).

Data kasus diabetes mellitus di Rumah Sakit Umum Daerah (RSUD) Dr. M. Yunus Bengkulu pada tahun 2015 berjumlah 355 orang, pada tahun 2016 berjumlah 359 orang, dan pada tahun 2017 berjumlah 369 orang.
Data ini menunjukkan adanya peningkatan jumlah pasien penderita diabetes melitus dari tahun ke tahun di RSUD Dr. M. Yunus Bengkulu (Sub Bidang Rekam Medic RSMY Bengkulu, 2018). Sedangkan data kasus diabetes mellitus di ruang Poliklinik pada tahun 2017 sebanyak 129 kasus. (Buku Register Ruang Poliklinik Penyakit Dalam, 2017).

Kepatuhan adalah ketaatan pasien dalam melakukan tindakan diit. Kepatuhan pasien berarti bahwa pasien harus meluangkan waktu dalam menjalani pengobatan yang di butuhkan (Potter \&Perry, 2006). Diet memegang peranan penting dalam tatalaksana penyakit DM. Kualitas diet penderita DM bergantung pada jenis makanan dan ukuran asupan yang dikonsumsi selama satu hari, untuk mengetahui kualitas diet telah dikembangkan beberapa instrumen pengukuran kualitas diet. Salah satu dari empat instrumen yang telah digunakan di Asia adalah Diet Quality Index International (DQI-I). DQI-I menilai empat aspek dalam kualitas 
diet yang meliputi variasi (variation), kecukupan (adequ acy), ukuran (moderation) dan keseimbangan keseluruhan (overall balance).

\section{Penatalaksanaan}

tersebut harus dilakukan sepanjang hidup sehingga kejenuhan dan masalah ketidakpatuhan dalam penatalaksanaan DM sering terjadi. Hasil penelitian pada 600 pasien, menunjukkan hanya $16,6 \%$ yang patuh terhadap pengobatan anti-diabetik, $23,3 \%$ patuh terhadap pengaturan diet dan $31,7 \%$ patuh untuk melakukan latihan fisik (Sharma et al, 2014). Dengan terjadinya ketidakpatuhan pada penderita DM maka akan mengakibatkan kadar gula darah menurun atau meningkat melebihi dari batas normal sehingga akan menimbulkan komplikasi bahkan kematian (IDF, 2013).

Penelitian yang dilakukan oleh Sari (2012) pada 75 pasien DM menemukan bahwa manfaat edukasi dapat meningkatkan pengetahuan, kepercayaan diri, dan perilaku penderita DM. Kunci utama diet pada DM adalah 3J yaitu, jumlah kalori, jenis makanan, dan jadwal makanan. Manfaat diet adalah untuk mencapai dan mempertahankan berat badan serta memastikan asupan yang cukup seperti karbohidrat, serat, lemak dan asam amino esensial, protein, vitamin, dan mineral. Diet dapat menurunkan dan mengendalikan berat badan, dapat meningkatkan kualitas hidup, dapat mengendalikan kadar gula darah dan kolesterol,sehingga diet pada DM dapat menunda atau mengurangi resiko terjadinya komplikasi pada DM (Hartono, 2006).

Penelitian lain dari Lestari (2013) pada 29 penderita DM menunjukkan bahwa $65,5 \%$ penderita DM tidak patuh terhadap jenis makanan, $89,7 \%$ penderita tidak patuh mengkonsumsi makanan sesuai jumlah kalori, dan $100 \%$ penderita DM tidak patuh terhadap jadwal makanan.

Diet membutuhkan pengetahuan untuk dapat diaplikasikan dengan baik. Pengetahuan didapatkan 
melalui edukasi. Penelitian Purwanto (2013) pada 60 penderita DM menunjukkan bahwa $35 \quad(58,3 \%)$ responden tidak patuh dalam pelaksanaan diet DM dikarenakan kurangnya informasi. Edukasi pada umumnya dilakukan dengan cara bertemu secara langsung, akan tetapi terdapat beberapa hambatan seperti keterbatasan waktu, membutuhkan transportasi, dan menyita banyak waktu (Sari, 2012).

Penelitian dari Insiyah (2014) pada 45 penderita DM menunjukkan bahwa lebih dari $65 \%$ responden belum dapat mematuhi diet terkait jenis makanan, jumlah makanan, dan jadwal makan karena pasien belum mampu menetapkan jumlah kalori yang harus dikonsumsinya perhari dalam jumlah yang lengkap. Berdasarkan pengalaman yang telah dilewati oleh penulis selama praktik di RSUD Dr. M. Yunus Bengkulu pasien yang menderita Diabetes Melitus tidak menjalankan diet yang dianjurkan oleh perawat ruangan.
Dari data-data diatas peneliti tertarik untuk mengangkat gambaran kepatuhan diit pada pasien Diabetes Melitus di ruang Melati RSUD Dr. M. Yunus Bengkulu.

\section{METODE PENELITIAN}

Penelitian ini menggunakan metode rancangan studi kasus berupa deskriptif yang bertujuan untuk menggambarkan kepatuhan diet pada pasien diabetes mellitus di Ruang Poliklinik Penyakit Dalam RSUD dr. M. Yunus Bengkulu tahun 2018.

Pengambilan sampel dilakukan pada seluruh pasien yang menderita DM yang berobat di Poliklinik Penyakit Dalam RSUD Dr. M. Yunus Bengkulu. Sampel dilakukan random berdasarkan rumus Arikuntoro (2010). Penentuan besarnya sampel apabila subjek/populasi <100 maka subjek/ populasi diambil semua, sedangkan subjek/populasinya $>100$ maka diambil antara $10-15 \%$ atau $20-25 \%$ dari total populasi. Rumus yang 
digunakan untuk pengambilam sampel

$$
\text { adalah : } \quad \mathrm{n}=10 \% \times \mathrm{N}
$$

menjadi 13

$$
\begin{aligned}
& \mathrm{n}=0,10 \times 129 \\
& \mathrm{n}=\quad 12,9 \quad \text { dibulatkan }
\end{aligned}
$$

$$
\begin{aligned}
& \mathrm{n}=13 \text { sampel } \\
& \text { keterangan : } \\
& \mathrm{N}=\text { Besar populasi } \\
& \mathrm{n}=\text { Besar sampel }
\end{aligned}
$$

Berdasarkan hasil perhitungan, sampel dalam penelitian ini adalah 13 sampel. Dalam pengambilan sampel kriteria yang ditetapkan oleh peneliti yaitu : Pasien yang mengalami DM tipe I dan II yang berobat jalan di Poli Penyakit Dalam RSUD Dr. M. Yunus Bengkulu, Usia 40-65 tahun, Pasien yang pernah mendapatkan penkes diet dari tenaga kesehatan.

\section{Instrument Penelitian}

$\begin{array}{ccc} & \text { Intrument yang digunakan } \\ \text { dalam pengukuran kepatuhan diit } \\ \text { adalah kuisioner kepatuhan diit. }\end{array}$
Intrumen ini telah baku dan banyak digunakan dalam penelitian kepatuhan diit seperti dalam penelitian (Amalia , 2013). Kuesinoner kepatuhan diit terdiri dari 18 pertanyaan. Kuesioner kepatuhan diet DM berisi pertanyaan mendukung (favorable) sebanyak 8 pertanyaan yaitu pada nomor 1, 2, 3, 4, 5, 6, 7 dan 8 dengan skor 1-4 yaitu “ tidak pernah" dengan point 1 , "jarang" dengan point 2, " sering" dengan point 3, "selalu" dengan point 4 dan pertanyaan tidak mendukung (unfavorable) sebanyak 10 pertanyaan yaitu pada nomor $10,11,12,13,14$, $15,16,17$, dan 18 dengan skor 1-4 yaitu "tidak pernah" dengan point 4 , "jarang" dengan point 3, "sering" dengan point 2 dan "selalu" dengan point 1. Prosedur pengambilan data ini dilakukan dengan cara didampingi oleh peneliti dan peneliti melibatkan anggota keluarga

\section{Variable Penelitian}

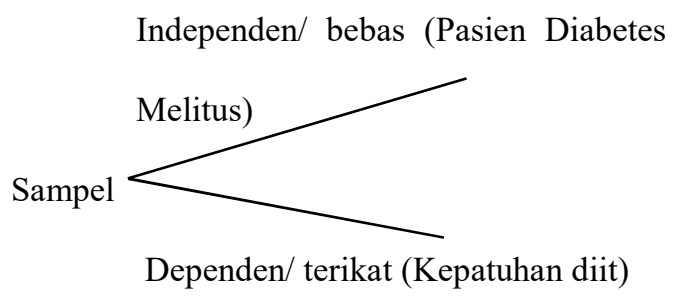

\section{Uji Validitas}


Kuesioner yang diberikan kepada responden tidak dilakukan uji validitas

Deskripsi Karakteristik Responden

Tabel 4.1 Distribusi Frekuensi Dan Persentase Responden Berdasarkan Karakteristik Responden $(\mathrm{N}=13)$

Deskripsi karakteristik pasien

\begin{tabular}{ccc}
\hline Karakteristik & $\mathrm{F}$ & $\%$ \\
\hline \multirow{3}{*}{ Umur } & $\begin{array}{c}41-50 \\
\text { tahun }\end{array}$ & $31 \%$ \\
\cline { 2 - 3 } & $\begin{array}{c}51-60 \\
\text { tahun }\end{array}$ & $54 \%$ \\
\cline { 2 - 3 } & $\begin{array}{c}61-65 \\
\text { tahun }\end{array}$ & $15 \%$ \\
\hline \multirow{2}{*}{ Jenis Kelamin } & \begin{tabular}{c} 
Perempuan \\
\cline { 2 - 3 }
\end{tabular} & $38 \%$ \\
\hline \multirow{2}{*}{ Laki-Laki } & $62 \%$ \\
\cline { 2 - 3 } Pendidikan & SD & $15 \%$ \\
\cline { 2 - 3 } & SMA & $31 \%$ \\
\cline { 2 - 3 } & D3 & $8 \%$ \\
\cline { 2 - 3 } & S1 & $38 \%$
\end{tabular}

diabetes mellitus di ruang Poliklinik Penyakit Dalam RSUD Dr. M. Yunus Bengkulu didapatkan 13 responden. Berdasarkan rentang usia 41-50 tahun 4 orang berusia sebanyak (31\%) responden, sedangkan rentang usia 5160 tahun 7 orang (54\%), dan rentang usia 61-65 tahun 2 orang (15\%), berdasarkan jenis kelamin didapatkan mayoritas laki-laki yaitu 8 responden $(62 \%)$ dan minoritas perempuan yaitu 5 responden (38\%) . Untuk tingkat pendidikan, pendidikan SD 2 orang (15\%) responden, pendidikan SMP 1 orang $(8 \%)$ responden, pendidikan SMA 3 orang $(23 \%)$ responden, pendidikan D3 1 orang (8\%) responden, dan pendidikan S1 6 orang $(46 \%)$ responden

Deskripsi Kepatuhan Diet Responden Berdasarkan Parameter Kepatuhan Diet $(n=13)$

Tabel 4.2 Distribusi Frekuensi dan Persentase Kepatuhan Diet Berdasarkan Parameter Kepatuhan Diet $(n=13)$

\begin{tabular}{l}
\hline $\begin{array}{l}\text { Parameter } \\
\text { Kepatuhan } \\
\text { Diet }\end{array}$ \\
Pasien makan \\
tepat waktu \\
sesuai jadwal \\
yang sudah \\
dikonsultasik \\
an oleh \\
petugas \\
kesehatan \\
\hline Selalu
\end{tabular}




\begin{tabular}{llc}
\hline Sering & 7 & $54 \%$ \\
\hline Jarang & 4 & $31 \%$ \\
\hline Tidak pernah & - & \\
\hline $\begin{array}{l}\text { Pasien makan } \\
\text { makanan } \\
\text { yang sesuai } \\
\text { anjuran } \\
\text { petugas } \\
\text { kesehatan }\end{array}$ & & \\
\hline $\begin{array}{l}\text { Selalu } \\
\text { Sering }\end{array}$ & & \\
\hline $\begin{array}{l}\text { Jarang } \\
\text { Tidak pernah }\end{array}$ & - & - \\
\hline $\begin{array}{l}\text { Pasien setiap } \\
\text { hari } \\
\text { mengkonsum } \\
\text { si makanan } \\
\text { yang banyak } \\
\text { mengandung } \\
\text { vitamin dan } \\
\text { mineral } \\
\text { (umbi- } \\
\text { umbian, } \\
\text { kacang- } \\
\text { kacangan, } \\
\text { susu tanpa } \\
\text { lemak, buah }\end{array}$ & & \\
jambu \\
merah, dll)
\end{tabular}

hari selalu

makan sayur

dan buah

sesuai

dengan

anjuran

dokter

\begin{tabular}{lcc}
\hline Selalu & 3 & $23 \%$ \\
\hline Sering & 5 & $39 \%$ \\
\hline Jarang & 5 & $38 \%$ \\
\hline Tidak pernah & - & - \\
\hline $\begin{array}{l}\text { Setiap bulan } \\
\text { pasien secara } \\
\text { rutin } \\
\text { menimbang } \\
\text { berat badan }\end{array}$ & & \\
\end{tabular}

\begin{tabular}{lcc}
\hline Selalu & 2 & $15 \%$ \\
\hline Sering & 4 & $31 \%$ \\
\hline Jarang & 6 & $46 \%$ \\
\hline Tidak pernah & 1 & $8 \%$ \\
\hline
\end{tabular}

Pasien secara

rutin

mengontrol

kadar gula

darah ke

puskesmas/

pelayanan

kesehatan

yang lain

untuk

menentukan

kebutuhan

diet.

Selalu

5

$38 \%$ 


\begin{tabular}{|c|c|c|}
\hline Sering & 4 & $31 \%$ \\
\hline Jarang & 4 & $31 \%$ \\
\hline Tidak pernah & - & - \\
\hline $\begin{array}{l}\text { Pasien selalu } \\
\text { melakukan } \\
\text { variasi } \\
\text { makanan } \\
\text { pada jadwal } \\
\text { diet makan } \\
\text { pasien agar } \\
\text { tidak terjadi } \\
\text { kebosanan }\end{array}$ & & \\
\hline Selalu & - & - \\
\hline Sering & 1 & $8 \%$ \\
\hline Jarang & 12 & $92 \%$ \\
\hline Tidak pernah & - & - \\
\hline $\begin{array}{l}\text { Pasien } \\
\text { memakai } \\
\text { gula } \\
\text { pengganti } \\
\text { seperti gula } \\
\text { jagung pada } \\
\text { saat ingin } \\
\text { mengkonsum } \\
\text { si minuman/ } \\
\text { makanan } \\
\text { yang manis. }\end{array}$ & & \\
\hline Selalu & 4 & $31 \%$ \\
\hline Sering & 1 & $7 \%$ \\
\hline Jarang & 1 & $8 \%$ \\
\hline Tidak pernah & 7 & $54 \%$ \\
\hline $\begin{array}{l}\text { Pasien setiap } \\
\text { hari } \\
\text { mengkonsum } \\
\text { si makanan }\end{array}$ & & \\
\hline
\end{tabular}

yang banyak mengandung protein seperti telur dan daging

\begin{tabular}{llc}
\hline Selalu & 1 & $8 \%$ \\
\hline Sering & 4 & $31 \%$ \\
\hline Jarang & 8 & $61 \%$ \\
\hline Tidak pernah & - & - \\
\hline Pasien terlalu & & \\
sibuk dengan \\
urusannya \\
sehingga \\
pasien makan \\
tidak tepat \\
waktu.
\end{tabular}

\begin{tabular}{|c|c|c|}
\hline Selalu & - & - \\
\hline Sering & 6 & $39 \%$ \\
\hline Jarang & 5 & $46 \%$ \\
\hline Tidak pernah & 2 & $15 \%$ \\
\hline $\begin{array}{l}\text { Pasien setiap } \\
\text { hari } \\
\text { mengkonsum } \\
\text { si makanan } \\
\text { dan } \\
\text { minuman } \\
\text { yang terasa } \\
\text { manis/ } \\
\text { banyak } \\
\text { mengandung } \\
\text { gula }\end{array}$ & & \\
\hline Selalu & 2 & $15 \%$ \\
\hline Sering & 6 & $46 \%$ \\
\hline Jarang & 3 & $23 \%$ \\
\hline
\end{tabular}




\begin{tabular}{|c|c|c|}
\hline Tidak pernah & 2 & $16 \%$ \\
\hline $\begin{array}{l}\text { Pasien suka } \\
\text { makan } \\
\text { makanan } \\
\text { yang asin- } \\
\text { asin }\end{array}$ & & \\
\hline Selalu & - & - \\
\hline Sering & 5 & $38 \%$ \\
\hline Jarang & 8 & $62 \%$ \\
\hline Tidak pernah & - & - \\
\hline $\begin{array}{l}\text { Pasien selalu } \\
\text { makan } \\
\text { makanan } \\
\text { kecil/ ngemil }\end{array}$ & & \\
\hline Selalu & 3 & $23 \%$ \\
\hline Sering & 7 & $54 \%$ \\
\hline Jarang & 3 & $23 \%$ \\
\hline Tidak pernah & - & - \\
\hline $\begin{array}{l}\text { Jadwal } \\
\text { aturan } \\
\text { makan/ diet } \\
\text { yang } \\
\text { dianjurkan } \\
\text { terasa berat } \\
\text { bagi pasien }\end{array}$ & & \\
\hline Selalu & 1 & $8 \%$ \\
\hline Sering & 8 & $62 \%$ \\
\hline Jarang & 3 & $23 \%$ \\
\hline Tidak pernah & 1 & $8 \%$ \\
\hline $\begin{array}{l}\text { Pasien tidak } \\
\text { mencatat }\end{array}$ & & \\
\hline
\end{tabular}

\begin{tabular}{|c|c|c|}
\hline $\begin{array}{l}\text { menu } \\
\text { makanan } \\
\text { setiap hari }\end{array}$ & & \\
\hline Selalu & 8 & $61 \%$ \\
\hline Sering & 4 & $31 \%$ \\
\hline Jarang & 1 & $8 \%$ \\
\hline Tidak pernah & - & - \\
\hline $\begin{array}{l}\text { Pasien setiap } \\
\text { hari } \\
\text { mengkonsum } \\
\text { si makanan } \\
\text { yang banyak } \\
\text { mengandung } \\
\text { minyak/ } \\
\text { tinggi lemak } \\
\text { seperti } \\
\text { makanan siap } \\
\text { saji (fast } \\
\text { food), } \\
\text { gorengan, } \\
\text { usus, dan } \\
\text { hati }\end{array}$ & & \\
\hline Selalu & 1 & $8 \%$ \\
\hline Sering & 3 & $23 \%$ \\
\hline Jarang & 8 & $61 \%$ \\
\hline Tidak pernah & 1 & $8 \%$ \\
\hline $\begin{array}{l}\text { Setiap hari } \\
\text { pasien makan } \\
\text { lebih dari } \\
\text { porsi } \\
\text { kebutuhan } \\
\text { tubuh pasien. }\end{array}$ & & \\
\hline Selalu & - & - \\
\hline
\end{tabular}




\begin{tabular}{llc}
\hline Sering & 3 & $23 \%$ \\
\hline Jarang & 5 & $28 \%$ \\
\hline Tidak pernah & 5 & $39 \%$ \\
\hline $\begin{array}{l}\text { Pasien tidak } \\
\text { mau } \\
\text { mentaati } \\
\text { aturan } \\
\text { makan } \\
\text { penderita } \\
\text { DM karena } \\
\text { menyusahka } \\
\mathrm{n}\end{array}$ & & \\
\hline $\begin{array}{l}\text { Selalu } \\
\text { Sering }\end{array}$ & - & - \\
\hline $\begin{array}{l}\text { Jarang } \\
\text { Tidak pernah }\end{array}$ & 1 & $8 \%$ \\
\hline
\end{tabular}

Berdasarkan penelitian yang dilakukan peneliti terdapat 13 responden di ruang Poliklinik Penyakit Dalam RSUD Dr. M. Yunus Bengkulu peneliti memperoleh hasil yaitu pasien makan tepat waktu sesuai jadwal yang sudah dikonsultasikan oleh petugas kesehatan yaitu 2 orang (15\%) selalu melakukan, 7 orang (54\%) sering melakukan dan 4 orang (31\%) jarang melakukan, pasien makan makanan yang sesuai anjuran petugas kesehatan yaitu 7 orang (54\%) sering melakukan, dan 6 orang (46\%) jarang melakukan, pasien rutin mengontrol kadar gula darah yaitu 5 orang (38\%) selalu melakukan, 4 orang $(31 \%)$ sering melakukan, dan 4 orang (31\%) jarang melakukan, pasien mengganti gula pengganti seperti gula jagung yaitu 4 orang selalu melakukan, 1 orang (7\%) sering melakukan, 1 orang (8\%) jarang melakukan dan 7 orang (54\%) tidak pernah melakukan..

\section{Deskripsi Kepatuhan Diet}

Tabel 4.3 Distribusi Frekuensi dan Persentase Berdasarkan Kepatuhan Diet Pasien Diabetes Mellitus di Ruang Poliklinik RSUD Dr. M. Yunus Bengkulu $(\mathrm{n}=13)$

$\begin{aligned} & \text { Kepatuhan } \\ & \text { Diet }\end{aligned}$
$\begin{aligned} & \text { Tidak Patuh } \\ & \text { 2 Orang }\end{aligned}$
Patuh
11 Orang
Hasil $85 \%$
menunjukkan bahwa hampir seluruh
patuh terhadap dietnya yaitu 11 orang
(85\%) responden, dan hanya sedikit
tidak patuh terhadap dietnya yaitu 2


orang $(15 \%)$ responden. Nilai skor minimum pada kepatuhan diet pasien diabetes mellitus adalah 36, maka apabila kurang dari 36 menandakan bahwa pasien tersebut tidak patuh terhadap diet yang berhubungan dengan penyakit yang dialaminya.

\section{Daftar Pustaka}

Almatsier, Sunita. 2010. Penuntun Diet. Edisi terbaru. Jakarta: PT SUN

A.,Nur, \& Aridiana, L.M., 2016. Asuhan Keperawatan Pada Sistem Endokrin : dengan pendekatan NANDA NIC NOC. Jakarta : Salemba Medika

American Diabetes Association. 2010. "Standards Of Medical Care In Diabetes 2010”. Vol. 40. USA : ADA

Arikuntoro. 2010. Prosedur Penelitian : Suatu Pendekatan Praktek. Jakarta: Rineka Cipta

Black.,M.J, \& Hawk, H.,J. 2009. Medical Surgical Nurding Clinic Management For Positive Outcomes. Volume 1. Jakarta : Salemba Medika

Brunner \& Suddarth. 2002. Buku Ajar Keperawatan Medikal Bedah. Edisi 8 volume 2. Jakarta: EGC
Dinkes. 2016.. Profil Kesehatan Provinsi Bengkulu Tahun 2016.

http://www.depkes.go.id/recour ces/download/profil/PROFIL KES PROVINSI 2016/07 Ben gkulu-2011.pdf Diakses pada tanggal 20 februari 2018

Hartono, A. 2006. Terapi Gizi \& Diet Rumah Sakit. Jakarta: EGC

IDF. 2013. IDF Diabetes Atlas Sixth Edition, International Diabetes Federation

2013.http://www.IDF.org.sites/ default/files/EN GE ATLAS FULL 0.pdf diakses pada tanggal 9 Februari 2018

IDF. 2015. IDF Diabetes Atlas Sixth Edition.

http://www.IDF.org.sites/defau 1t/files/ATLAS-Poster-2015EN.pdf diakses pada tanggal 12 Februari 2018

Lutfey, K.,E and Wishner, W.,J. 1999. Beyond "compliance" Is "Adherence" Diabetes Care. http//:www.care.diabetesjourna 1s.org/ diakses pada tanggal 28 Maret 2018

Medical Record RSUD Dr. M. Yunus Bengkulu. 2015. Rekapitulasi Jumlah Pasien Diabetes Melitus di RSMY

Katsilambros, N, dkk. 2011. Asuhan Gizi Klinik. Jakarta: EGC 
Natoatmodjo, S. 2012. Metodologi Penelitian Kesehatan. Jakarta: Rineka Cipta

Niven, N. 2002. Psikologi Kesehatan : Pengantar Untuk Perawat dan Professional. Jakarta: EGC

Nursalam. 2013. Metodologi Penelitian Ilmu Keperawatan. Edisi 3. Jakarta: Salemba Medika

Perkeni. 2015. Kosensus Pengelolaan dan Pencegahan Diabetes Mellitus Di Indonesia 2015. PB Perkeni

Potter, P.,A and Perry, A.,G. 2008. Buku Ajar Fundamental Keperawatan: Konsep, Proses, dan Praktik. Jakarta : EGC
Rikesdas. 2013. Laporan Hasil Riset Kesehatan Dasar (Riskesdas) tahun 2013. http//:www.depkes.go.id/recour ces/download/general/hasil\%20 Riskesdas\%202013.pdf diakses pada tanggal 20 Februari 2018

Smeltzer, S.,C and Bare, B.,G. 2013. Buku Ajar Keperawatan Medikal Bedah Brunner and Suddarth. Edisi 8 (H.Y Kuncara, Dkk, penerjemah). Jakarta: EGC

Smet, B. 1994. Psikologi Kesehatan. Jakarta: PT Grasindo 